\title{
Inter-business association and its effect on local economic
}

\section{Tania Nadiezhda Plascencia Cueva y Arianna del Carmen Beltrán Cruz}

\author{
Centro Especializado de Educación Virtual y Doctorado en Gestión de las Organizaciones \\ Universidad Autónoma de Nayarit, México \\ Unidad Académica de Economía \\ Universidad Autónoma de Nayarit, México
}

\begin{abstract}
The micro, small and medium-sized enterprises (MSMEs) are exposed to a several situations external to their main activities, for that reason MSMEs are forced to develop new strategies that allow them to continue in the business, even in the adversity. In addition, the business association has become a relevant issue in the public and private agenda, because this is a way for the MSMEs to increase their competitiveness and achieve specific objectives, which if done individually it would be a slower process and with less impact for the local economic development. With this background, the objective of this research is to determinate if in Tepic City, Nayarit, the inter-business associations serve or can serve as a strategy for boost the economic development of the area. A semi-structured interview was conducted with two established inter-business associations: Association of Automobile Distributors of Nayarit, and Tepic Hotels and Motels Association. The main result is that the currently established business associations have as main motivation to have power of decision in the sector, moreover to have representation in front of government policies, without forgetting the join structure which has allowed them to improve their quality and training.
\end{abstract}

Keywords: Business Association, MSMEs, Local Economic Development, Business Strategies

\section{Asociación interempresarial y su efecto en el desarrollo económico local}

$\mathrm{Al}$ estar expuestas a un sin número de situaciones externas a su actividad, las micro, pequeñas y medianas empresas (mipymes) están obligadas a desarrollar nuevas estrategias que les permita continuar en el negocio aun en la adversidad. En este sentido, la asociación o articulación empresarial se ha vuelto un tema relevante en la agenda pública y privada, ya que es una forma para que las empresas puedan aumentar su competitividad; y alcanzar objetivos específicos, que, de hacerse de manera individual, requerirían de un proceso más lento y de menor impacto para la localidad donde se desarrollan. A partir de estas consideraciones, el objetivo de esta investigación es determinar si, en la ciudad de Tepic, Nayarit, las asociaciones empresariales establecidas sirven como estrategia para impulsar el desarrollo económico de la zona. Para ello, se aplicó una entrevista semiestructurada a dos asociaciones empresariales establecidas: la Asociación de Distribuidores de Automotores de Nayarit, A.C. y la Asociación de Hoteles y Moteles de Tepic. El principal resultado consiste en que las asociaciones actualmente establecidas tienen como principal motivación el tener poder de decisión en el sector, además de tener representación frente a las políticas gubernamentales, sin dejar de lado que la estructura conjunta les ha permitido mejorar su calidad y capacitación.

Palabras clave: asociación empresarial, mipymes, desarrollo económico local, estrategias empresariales 


\section{Associação entre negócios e seu efeito no desenvolvimento econômico local}

As micro, pequenas e médias empresas (MPME) estão expostas a inúmeras situaçôes externas à sua atividade, por esse motivo as MPME são forçadas a desenvolver novas estratégias que lhes permitam continuar nos negócios, mesmo na adversidade. Além disso, a associação entre negócios tornou-se uma questão relevante na agenda pública e privada, pois é uma maneira de as MPME podem aumentar sua competitividade e alcançarem objetivos específicos que, se fossem feitos individualmente, seriam um processo mais lento e com menos impacto para a localidade em que são desenvolvidos. Com base nisso, o objetivo desta investigação é determinar se, na cidade de Tepic, Nayarit, as associaçóes entre negócios estabelecidas servem como uma estratégia para impulsionar o desenvolvimento econômico da regiāo. Uma entrevista semiestruturada foi realizada a duas associaçôes entre negócios estabelecidas: a Associação dos Distribuidores Automotivos de Nayarit e a Associação Tepic de Hotéis e Motéis. O principal resultado é que as associaçôes entre negócios atualmente estabelecidas têm como principal motivação ter poder de decisão no setor, além de ter representação diante das políticas governamentais, sem esquecer a estrutura de união que lhes permitiu melhorar sua qualidade e treinamento.

Palavra chave: Associação empresarial, MPME, desenvolvimento econômico local, estratégias de negócios.

\section{Introduction}

In the last decade, research on the different forms of articulation or business association has experienced an increase, since these strategies can bring various benefits to organizations and, in addition, allow regions to achieve better levels of economic development. Strategies have been sought that aim to potentiate the development of business sectors, and also, promote economic growth and the competitive capacity of localities (Narváez, Fernández, \& Senior, 2008). Likewise, authors such as Silva (2005), Valdés and Sánchez (2012) and Fuentes, Osorio and Mungaray (2016) point out the important role that micro, small and medium enterprises (MSMEs) play and the relevance of it in any region and as these enterprises are as fundamental piece in the local economic development. Following the before mentioned authors, MSMEs must innovate in the creation and adaptation of strategies that allow them to stay and in turn, take the next step, that is, change size, professionalize, adapt to the business environment of the area and also, find a way to be decisive in the decision making of the sector; all this to generate greater sources of employment and return some of the benefits to the society in which they operate.
According to Silva (2005), in order for MSMEs to develop their competitiveness, they need to associate and public policies to help them in the training of their human resources and in technological innovation, as well as to face market failures mainly linked to the imperfection of the capital, financing and credit markets. In this sense, Narváez et al. (2008) mention that it is essential that those public policies start from a vision of integration of the conglomerate of agents and institutions, both public and private, with an impact on the territory, because there is evidence of the interrelationship between the processes of local economic growth and development, and between business and local competitiveness.

Therefore, the present investigation has as general objective to determine whether in Tepic City established inter-business associations serve as a strategy to promote the economic development of the area. Among the main results, it was found that the associations studied were created and maintain the objective of having an impact on the sector in which they operate and, above all, having a voice before the governmental decision-making structures. Therefore, evidence was found in favor of the benefits of producing through 
inter-business associations, however, it is considered that these could be linked even more, and thus obtain greater benefits, such as in training, decreasing prices with suppliers or even in seasonal marketing strategies, with emphasis on low seasons.

\section{Inter-business association and its effect on local economic development}

There is much research on the importance of establishing strategies that promote economic and social development, starting from the particular to the general, which is to promote the development of the localities, in order to have a real and sustained impact in the global. In Narváez et al. (2008) it is discussed that the local development is the product of coordinating efforts in an organized way, and the communities need primarily to promote processes of effective business connections, thus optimize resources, increase productivity and make companies more likely to remain in the market.

As shown in Figure 1, one of the links in the chain of activities or strategies for achieving local or regional economic development relates to cooperation or inter-business association, and they form part of a production system that establishes the conditions for raising the level and quality of life in communities. In such a way, the productive articulation can be assumed as a collaboration agreement between different economic actors, oriented to the generation of competitive benefit, where the individual economic agents make collaborative arrangements to develop actions, the results of which would not be achieved by acting independently or in isolation, which would not be justified on an individual basis (Dini, 2010).
Figure 1. Economic Development Process

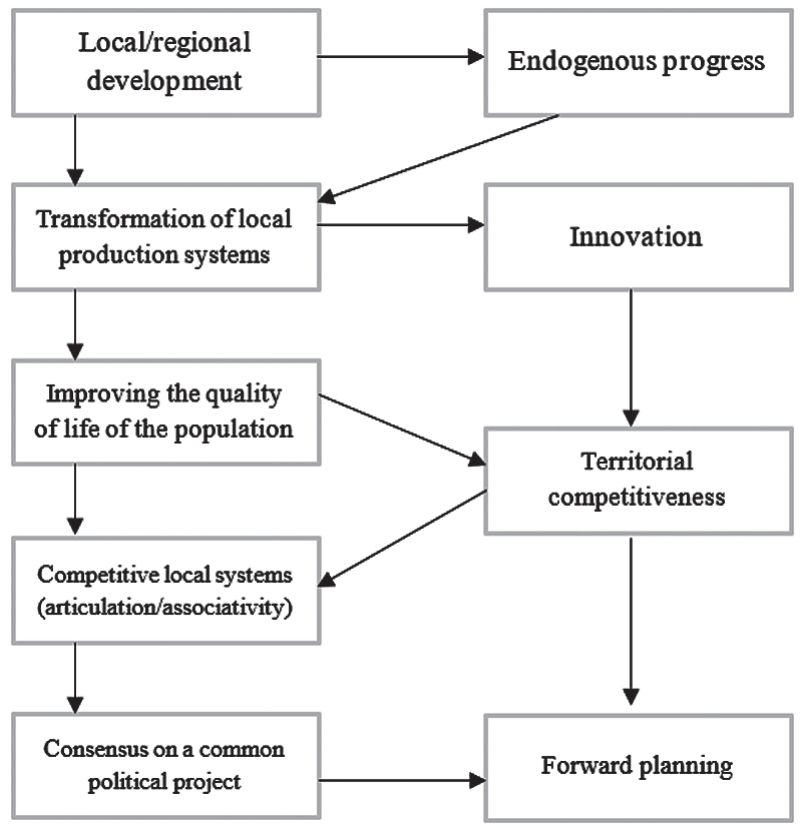

Source: Silva, 2005.

According to Silva (2005) the business success of MSMEs derives from the integration or articulation of productive, economic and social systems, dynamic at the local level, in such a way that it results in economies of scale and its scope is strong enough to be able to compete with large companies in the global market. Moreover, Felzensztein and Gimmon (2009) point out that the need for associativity of MSMEs is an essential element and an instrument to promote its competitiveness.

Stejskal (2011) in his study of clusters ${ }^{1}$, mentions that cooperation and the relations establishes between companies and institutions of public administration are fundamental, since clusters or any business association are closely linked to the competitiveness of a

${ }^{1}$ Clusters are one of many existing forms of business association. 
specific sector, region and nation. Likewise, in Safón and Castelló-Sirvent (2018) it is affirmed that business association are important for economic development, also it is a type of formal business networks that allow entrepreneurs to connect with common interests.

On the other hand, a study by Chang, Chen, Lin, and Gao (2012) mention that associativity is closely related to the cultural elements of the company, particularly the culture of cooperation. Therefore, it seems necessary to search for instruments that facilitate the path towards associativity in MSMEs. However, business associations, as meta-organizations, are a powerful resource for entrepreneurs and managers, especially regarding information gathering and influence on the environment. In addition to being an important source of economic value generation (Gulati, Puranam \& Tushman, 2012; Lundrigan, Gil \& Puranam, 2015; Matinheikkia, Pesonen, Artto, \& Peltokorpi, 2017).

Thus, according to Castrillo (2019), the main objectives of business association are based on: 1) to promote and defend the system of private initiative and free market economy; 2) to promote and defend unity and business integration; 3) to promote economic development of the locality; and, 4) to represent the general and common business interests before society and the government.

It is important to note that nowadays there are various forms of association or cooperation, since enterprises must be adapted to the sector or specific activity of the companies involved, the most commonly used are clusters, geographic or virtual, value chains, industrial districts, among others. The aim of successful inter-business associations is to benefit from all the activities that can be done together, such as investing in technology, increasing staff training, reducing vendor costs, among others. However, there are reasons why entrepreneurs do not opt for this type of strategy, the main reason being the rivalry between enterprises of the same sector and the fear of losing customers.

Therefore, it should be mentioned that not all enterprises are in position to work in an articulated way, due to the need for trust between the protagonists, availability, common objectives, economic and human resources, and expected results. With all above, it can be inferred that a successful inter-business association generates replicable procedures to other sectors, making their production pay for development, which translates into providing or returning to society something that improves the conditions for all.

\section{Micro, small and medium-sized enterprises}

The micro, small and medium-sized enterprises (MSMEs) are independent companies that employ a certain number of people and play an important role in the growth of the various stages of economic development, for that reason, MSMEs are seen as the cornerstone of the private sector in the world (Valdés \& Sánchez, 2012; Ensari \& Karabay, 2014; Fuentes et al., 2016). In the other hand, in Beltrán (2016) it is mentioned that MSMEs are seen by the governments of advanced and developing economies as the largest economic driver and as a source of employment opportunities.

In Mexico, the National Institute of Geography and Statistics indicates that MSMEs are the most important economic force in the country (INEGI, 2014). In fact, the $90 \%$ of the population in Mexico is employed in this type of business, therefore, MSMEs influence the development of the territory where they are established (Vélazquez, 2007; Martínez, Aguilera \& Maldonado, 2011; Zúníga, 2013, Camacho, 
Morales, Flores, Aguilar, \& Hernández, 2013; Secretaría de Economía, 2014).

In addition, Ensari \& Karabay (2014) show, in general, the factors involved in the success of MSMEs, which can be classified into ten categories: entrepreneurial characteristics, characteristics of MSMEs, management, products and services, clients and markets, how to do business and cooperation strategy, resources and finance, strategies, external environment, and Internet. Nevertheless, the most significant factors influencing the failure of MSMEs are lack of managerial skills, managerial incapacity, understaffing, quality deficiencies, institutional weakness, lack of resources, negative economic conditions, lack of institutional support, lack of cooperation, networking and technical skills (Ensari \& Karabay, 2014). Similarly, in Camacho et al. (2013) it is mentioned that Mexican MSMEs have to face challenges such as the political, economic, social and cultural situation, as well as excessive bureaucracy and others.

\section{Methodology}

The twenty municipalities of Nayarit State were reviewed taking into account the number of MSMEs and the volume of sales and negotiation, in order to select as a non-probability analysis, the municipality with the highest number of MSMEs, highest sales and trading revenues. In this regard, Tepic City (the main city of the municipality with the same name) was chosen, which the capital of Nayarit State is also.

This research represents a cross-sectional comparative study with qualitative data through a semi-structured interview. The objective of the study was to determine whether in Tepic City established inter-business associations serve as a strategy to promote the economic development of the area. The central hypothesis was that inter-business associations have a favorable influence on the economic development of Tepic City.

The design of this research was formed in three stages, in order to expose the state of the art, as well as the current panorama and the advances of the study area regarding the inter-business association. In the first stage, a detailed review of the literature was carried out with the aim of to expose what inter-business associations mean for development, mainly to describe the general context of MSMEs and to determine how they can benefit from new business strategies, all through techniques and methods of groundwork. In the second stage, a descriptive research was carried out, from which it was possible to identify the public policies that promote association as a business strategy, in addition to the current overview of MSMEs in Tepic City. Finally, in the third stage, in June 2016, a semi-structured interview was conducted with two already established inter-business associations, in order to identify and document the practices that made it possible for them successful in Tepic City, Nayarit. Besides knowing if they are involved with actions with the community of their environment, conditions of their employees and commitments among the companies involved. The inter-business associations interviewed were: The Association of Automobile Distributors of Nayarit, and the Tepic Hotels and Motels Association; these are named to below as $\mathrm{A} 1$ and $\mathrm{A} 2$ respectively.

The semi-structured interview was conducted based on diagnostic questionnaires that correspond to the basic consulting, where the questions were grouped in the different areas of the companies that make up the association, such as human resources, market, administration and finance, and there are open questions about the background, main achievements and the near future. 


\section{Results}

\subsection{Public policies that promote inter-business association}

In the National Development Plan 2013-2018 there were no found any public policy specifically focused on the creation and/or promotion of inter-business association, however, there was found a strategy to encourage entrepreneurs and strengthen MSMEs, and within this strategy are following lines of action:

- To support the successful integration of MSMEs into the value chains of the most dynamic strategic sectors, with the greatest potential for growth and job creation, in agreement with the governments of the federal entities of the country.

- To support the business scaling of Mexican MSMEs.

- To increase the participation of MSMEs in productive chains, as well as their export capacity (Gobierno de la República, 2013).

On the other hand, in the Nayarit State Development Plan 2011-2017 (Gobierno del Estado de Nayarit, 2012), within the framework of public policies of integral development, the policy for the promotion of productive activities was found, which states:

To promote a better regulation and simplification of procedures through an efficient and transparent regulatory framework, which will speed up the opening of new formal enterprises and the competitive development of Micro, Small and Medium-sized Enterprises (MSMEs) and with the promotion of financing through the various federal and state development funds and the linkage between the various chambers, business organizations, associations, universities, federal entities, state entities, municipal entities, institutions and foundations (Gobierno del Estado de Nayarit, 2012, p. 15).

In addition, in the Municipal Development Plan of Tepic 2014-2017, within the program of promotion to the investment the following line of action was found: "To facilitate the access of enterprises and micro-enterprises to training schemes for competitiveness, as well as permanent advice for their financing" (XL Ayuntamiento de Tepic, 2014, p. 136).

For its part, the National Institute for Entrepreneurship (Instituto Nacional del Emprendedor [INADEM], 2019) has programs focused on MSMEs, led by the General Directorate of Programs for MSMEs, which aims to support them in upgrading their business skills through comprehensive training and consultancy projects aimed at increasing their productivity and competitiveness; also supports the opening of new franchise outlets; moreover, this institute supports entrepreneurs in integrating their product and/ or service offering into export consortia or some other business linkage model for export purposes, to promote and improve their competitive position in the international market, or to promote their internationalization.

\section{Micro, small and medium-sized enterprises in Tepic City, Nayarit}

In order to determinate the number of MSMEs located in Tepic City, the databases of the Mexican Business Information System (SIEM, 2016) were reviewed, and a total of 3105 MSMEs were found registered up to June 2016: 3057 micro-enterprises, 36 small enterprises and 12 medium-sized enterprises. It should be noted that the most MSMEs are active in the commercial sector (see Table 1). 
Table 1. MSMEs in Tepic City according with the Mexican Business Information System (SIEM, 2016)

\begin{tabular}{|c|c|c|c|c|}
\hline $\begin{array}{c}\text { Numbers of } \\
\text { employees }\end{array}$ & $\begin{array}{c}\text { Industrial } \\
\text { sector }\end{array}$ & $\begin{array}{c}\text { Commercial } \\
\text { sector }\end{array}$ & $\begin{array}{c}\text { Services } \\
\text { sector }\end{array}$ & TOTAL \\
\hline $1-10$ & 120 & 2.362 & 575 & 3.057 \\
$11-50$ & 4 & 10 & 22 & 36 \\
$51-250$ & 2 & 8 & 2 & 12 \\
TOTALS & 126 & 2.380 & 599 & 3.105 \\
\hline
\end{tabular}

Source: Sistema de Información Empresarial Mexicano (2016).

A study by Plascencia, Ramírez and Pérez (2014) found that MSMEs in Tepic City, Nayarit need to face several factors to achieve the aim of fostering local economic development, such as: a) the lack of specific information to measure their productivity, b) the nature of the organization of these enterprises is characterized by a low instruction of the managers, and c) they are enterprises that practically subsist at family level and in some way as self-employment. Similarly, in a study by Beltrán (2016) concerning commercial MSMEs in Tepic City, it was found that these enterprises are just beginning to apply ICT as a marketing strategy and to interact with their customers and suppliers, but they still have a lot of work to do in terms of research and development, in addition to including innovation in their production processes.

\subsection{Inter-business Associations in Tepic City, Nayarit}

\section{- Association of Automobile Distributors of Nayarit (A1)}

Until June 2016, all automobile distributors established in Tepic City were within this association, so it was formed by 12 concessionaires of different automobile brands, which can be seen in Table 2. However, at the time of the interview, 10 concessionaires appeared in the association's legal charter, since the newest ones in the city, Kia and Mazda, had yet to be protocolized. A1 has been operating since 1994, and its main motivation was to have legal representation before government authorities and the national Automobile Association; in addition, to claiming to group all automobile distributors in Tepic City, Nayarit, to perform certain services together as training employees, keeping car sales statistics in the city, generate local information and be stronger with government authorities. Thus, it can be said that the cooperation between enterprises involved was planned and only new car concessionaires can be added, so, each new brand that enters the city is invited to participate into the association.

\section{Table 2. Association of Automobile Distributors of Nayarit}

\begin{tabular}{|l|l|}
\hline \multicolumn{1}{|c|}{ Distributor } & \multicolumn{1}{|c|}{ Automobile brands } \\
\hline Ford Plasencia Nayarit & Ford \\
Álica Automotriz & Chrysler, Dodge and Jeep \\
Aeroplaza de Occidente & Chevrolet, GMC and Buick \\
Volkswagen Euro Alemana & Seat and Volkswagen \\
Honda Avante & Honda \\
Automotores Sierra & Nissan \\
Toyota Puerto Vallarta en & Toyota \\
Tepic & \\
Fiat Tepic & Fiat \\
Agencia Mitsubishi Tepic & Mitsubishi \\
Suzuki Tepic & Suzuki \\
Mazda Tepic & Mazda \\
Kia Tepic & Kia \\
\hline
\end{tabular}

In addition, it was indicated that $50 \%$ of the cars sold are of national origin, while the remaining percentage comes from Germany, Japan and United States of America, and the distribution of these vehicles is according to each automobile brand and concessionaire. It should be mentioned that, as an inter-business association, all automobile distributors do not share profits or contributions because, although they have a manager for the whole association, each company 
determines its accounting management, administration, sales policy, purchasing, promotion and marketing, monitoring of sales volumes, and quality indicators. In short, companies operate completely independently even though they belong to an interbusiness association, which allows them to have specific and clearly defined benefits.

It is important to point out that none of the companies involved in A1 are considered to be rivals, as they emphasize that the final consumer has, in most cases, a clear preference and determined by a specific automobile brand, being the decision factor generally by price and status quo. A1 rarely carries out social actions, only carries them out in case of natural disasters and together they have not received any award or distinction for their performance.

Regarding the number of employees, A1 states that the smallest enterprises have between 10 and 12 employees and the largest one has 80 employees, thus, all the enterprises in the A1 offer approximately 120 jobs. As for diversity (foreign people, indigenous, youth and sexual orientation) among employees of concessionaires, although there is no restriction on this, the majority of employees are young, those who pass online assessments and psychometric tests, that is, those who are considered to be more competent and capable are recruited. The average age of the employees is 40 years old, the average schooling is high school, but in many cases, they have higher education.

In the other hand, $100 \%$ of employees in $\mathrm{A} 1$ have social security, $70 \%$ are men and $30 \%$ are women; $100 \%$ are in permanent employment and $100 \%$ are full-time. Nevertheless, $100 \%$ of managers are men, while the highest position held by women is in the command immediately below the general manager. Also, only one case of an employee with physical disabilities is known. On another matter, $90 \%$ of the employees of A1 are trained, the frequency and proportion of training depends on the area, and in general, the training consists of online courses through e-mails and videoconferences, in addition to some courses offered in agreement with the association. Additionally, employees have the possibility of promotion and hence of professional growth. The A1 does not carry out actions for its employees, such as health week, breast cancer, awareness week, day care, family support, among other.

Moreover, it was mentioned in the interview the fact of being in association has not brought any benefit to the concessionaires in terms of fiscal stimuli, in addition, they do not know whether there are any public policies aimed at promoting the practices of business association or productive articulation, considering that being associated has not had any impact on individual business growth, the only thing they see as an advantage is that they are stronger before the government authorities and, therefore, when negotiating. Likewise, it was pointed out that up to the time of the interview, they have not received any governmental support for the association, however, they are about to implement a course with the support of the Office of the Procurator for the Protection of the Environment (PROFERA) for environmental matters.

\section{- Tepic Hotels and Motels Association (A2)}

Currently, there are 26 companies that are registered in this association, although only 22 or 23 are active, Table 3 shows the companies involved in a way classified by stars. The association began to function as such since 1985 , at that time the state and federal government launched projects to promote the development of certain sites and indicated in which hotels the officials should stay. 
Thus, it was that the companies were associated by their own will and interests, with the fundamental objective of being stronger in the face off the government authorities, as well as to have a formal representation before the national association of hotels and motels, segment the market, offer a better service and be able to set the base prices, so the way to join this association is by invitation or by decision of each company.

Table 3. Tepic Hotels and Motels Association

\begin{tabular}{|c|c|c|c|}
\hline 1-star & 2-star & 3-star & 4-star \\
\hline $\begin{array}{l}\text { Hotel } \\
\text { California }\end{array}$ & $\begin{array}{l}\text { Hotel } \\
\text { Tepic }\end{array}$ & $\begin{array}{l}\text { Hotel Las Palomas } \\
\text { Express }\end{array}$ & $\begin{array}{l}\text { Hotel Fray } \\
\text { Junípero }\end{array}$ \\
\hline \multirow[t]{10}{*}{$\begin{array}{l}\text { Hotel } \\
\text { Sarita }\end{array}$} & $\begin{array}{l}\text { Hotel } \\
\text { Humberto }\end{array}$ & Hotel Ibarra & Hotel Ne Kié \\
\hline & $\begin{array}{l}\text { Hotel } \\
\text { Marbella }\end{array}$ & $\begin{array}{l}\text { Hotel Sierra de } \\
\text { Álica }\end{array}$ & $\begin{array}{l}\text { Hotel Las } \\
\text { Palomas }\end{array}$ \\
\hline & & Hotel Paraíso & $\begin{array}{l}\text { Hotel Ejecutivo } \\
\text { Inn }\end{array}$ \\
\hline & & $\begin{array}{l}\text { Hotel Los Gira- } \\
\text { soles }\end{array}$ & $\begin{array}{l}\text { Hotel Hacienda } \\
\text { Las Higueras }\end{array}$ \\
\hline & & Hotel Santa Fe & Hotel Melanie \\
\hline & & Hotel Santa Lucía & Motel La Loma \\
\hline & & $\begin{array}{l}\text { Hotel Villa Las } \\
\text { Rosas }\end{array}$ & $\begin{array}{l}\text { Hotel Real de } \\
\text { Don Juan }\end{array}$ \\
\hline & & Hotel Bravo & Hotel San Jorge \\
\hline & & Hotel Cibrian & Hotel Valeria \\
\hline & & Hotel Aztlán & \\
\hline
\end{tabular}

All the companies of the association belong to different owners, with the exception of Hotel Las Palomas and Hotel Las Palomas Express. The owners of the total of these companies are not family to each other, however, in the interview it was mentioned that in most companies there is family succession, generally the owners or partners are the general managers themselves and at the time of retirement they give their place to their descendants.

As for the provisioners, it is indicated that they handle different types, due to the variety of services offered by each of the companies, however, all the provisioners are local and of different qualities. As in the previous case, the companies registered in the association have a general manager but each company is operated and managed individually, only in this case, there are decisions that if taken from the association, for example promotion and advertising, prices by category and stars, among others. They mention that because of the actions taken by the association, there are agreements or strategic alliances with airlines, and they promote the Bajío area and the city of Guadalajara

As for the rivalry, they consider that it does not exist among the associated companies, since each one is aware of its capacity, classification, and limitations. In addition, the lines of work are marked between them, the rates are agreed and respected, as well as the distribution of the lodging in the events scheduled and carried out in the city. Due to the good functioning that they consider they have had in the articulation of activities; they plan to include more companies and in the medium term with the opening of the Tepic-San Blas highway a link with the San Blas Hotel Association is achieved ${ }^{2}$.

It is important to mention that in the interview it was stated that the growth of individual companies has been greater since they work as an association, since then they have entered into a dynamic of continuous improvement through courses and training,

\footnotetext{
2 San Blas is a coastal municipality in the State of Nayarit that borders the municipality of Tepic to the east, and by the time this investigation was conducted, the new Tepic-San Blas highway was not yet inaugurated.
} 
also some of the Hotels have remodeled their facilities and increased the number of rooms. The reason for being in continuous improvement is to be competitive against hotel chains that may allow lower rates for being part of national or international chains.

When asked about productivity, reference was made that the indicator of hotels and motels is the collection of $3 \%$ of the lodging tax, prior to 2010 approximately 104300 dollars were collected per year from the tax, as of 2012 and 2013 increased this collection to 156400 dollars annually and then to 208530 dollars annually, as of June 2016 around 312800 dollars have been collected. Because the city of Tepic has hosted sporting events and the concerts that have taken place at the People's Auditorium, opened in 2013, hotels have been in greater demand and, in those cases, have established rates for 1-star, 2-star, 3-star and 4-star hotels.

The association's companies are open to incorporate new business strategies, among them are programs and actions of the Ministry of Tourism (Secretaría de Turismo [SECTUR]), as well as the hotel classification of this Secretariat. Among these programs and actions is the "Clean Point Quality Seal", which aims to promote the incorporation of good hygiene practices in the management models of micro, small and medium-sized tourism companies, in order to protect the health of their customers, their workers and communities (SECTUR, 2015). Another program is "Improve your Hotel" launched by the Ministry of Treasury (SHCP), SECTUR, the National Foreign Trade Bank (Banco Nacional de Comercio Exterior [Bancomext]) and commercial banking, this with the purpose of improving tourism infrastructure and raise the quality of services offered by hotels in Mexico to both national and international tourists (SECTUR, 2016).
They also mentioned the "MODERNIZA" program of SECTUR (2011), which consists of training, that facilitates MSMEs to incorporate into their way of operating effective tools and modern administrative practices, which allow them to improve customer satisfaction, improve the performance of its staff, improve business control; reduce waste; increase its profitability, in order to make the company more competitive so that it can offer quality services to tourists and promote the development of a culture of continuous improvement.

Although the association does not have fiscal benefits and does not know if there are public policies specifically established to promote business association or productive articulation in its different forms, they make use of the tools proposed by government agencies, for example the electronic system "Compranet ", Where the association's companies can be providers of state and federal government, are also promoted through the website of the Tepic AC Visitors and Conventions Office. Likewise, it was commented that the government support they receive is a way Training provided by SECTUR, as it is $100 \%$ free, also receive training from the Ministry of Labor and Social Welfare (STPS), as well as courses and talks from National Financial (NAFIN).

Regarding the sources of employment, it is estimated that among all the companies in the association have between 600 and 700 employees, the smallest hotels have between 6 and 9 employees and the largest have up to 60 employees. It was also expressed that the average hotel occupancy in the year in the city of Tepic is approximately $54 \%$, which does not allow to have a high or very low workforce. However, it does not carry out activities for social purposes and has no actions in favor of its employees, such as nursery, health week, family support, among others. 
There is no specific policy in the hiring processes in terms of diversity (foreigners, youth, indigenous people, sexual orientation), there are many young employees in middle and lower management, they are mostly graduates of the Autonomous University of Nayarit, Tepic Technological Institute, Technological University of Nayarit, Univer University, Vizcaya University, Nueva Galicia University, Matatipac Institute and National College of Technical Professional Education. It was asserted that each company is responsible for training its employees, encouraged by the association, as they are constantly reviewed by the Secretariats of Tourism: federal, state, and municipal. Likewise, they are reviewed by the STPS, the Ministry of Labor and Productivity and Economic Development (SETRAPRODE), and the main office of Civil Protection of the Municipality.

There is no specific age average for company employees, however, it is estimated that the youngest employees are 18 years old and the oldest are approximately 55 years old. Regarding the average education level of the employees, many are university graduates, however, it is possible to find people with primary level in the lowest positions, but on average the employees have finished secondary school.

$100 \%$ of employees have social security, $35 \%$ are men and $65 \%$ are women. Likewise, $100 \%$ of employees are full-time, with 8-hour work hours and, between 70 and $80 \%$ of jobs are fixed, this is due to the fluctuation of hotel occupancy, as Tepic is not a destination tourist seasonally as is the coastal area of the state. It is worth mentioning that there are no women managers in the association's companies, but between 35 and $40 \%$ of middle managers are women. There are also no employees with any disability or part-time. On the other hand, employees do have the possibility of promotion, and depending on their skills they are promoted.
Likewise, the two associations were asked about the realization of some provisions regarding their human resources, and they were also asked to comment on this, in order to learn more about their personnel management and find points in common between the two, and from this make a comparison, which is presented in Table 4.

From all the above, it can be noted that both associations coincide in several aspects, highlighting mainly that they have been created fundamentally to deal with the governmental structure and have legal representation before national associations, of automotive distributors and hotels and motels respectively. Other common points they presented were that the companies are managed independently and do not present rivalry between them.

However, it is important to note that in the course of time the companies of the two associations have been favored with the benefits of belonging to an association because this has allowed them to have training for their human resources, to control the sector to some extent, so how to grow economically and have interference in the price level of your product or service.

In addition, these companies, being local, promote economic and social development, since the greater and better conditions the inhabitants have, and there is improvement of the infrastructure and the reduction of unemployment, the better the business conditions where these already established associations are developed and positioned, as well as those that are about to emerge.

As it was seen in the results it can be seen that practically both associations were created to have a voice before the governmental instances and weight in the sector, to determinate prices and promotional rates, however, there are no indicators as a whole 
Table 4. Comparison of Associations' Position on Human Resources

\begin{tabular}{|c|c|c|c|c|c|c|}
\hline \multirow{2}{*}{$\begin{array}{l}\text { The enterprise carries out the } \\
\text { following: }\end{array}$} & \multicolumn{3}{|r|}{ A1 } & \multicolumn{3}{|r|}{$\mathrm{A} 2$} \\
\hline & Yes & No & Commentaries & Yes & No & Commentaries \\
\hline $\begin{array}{l}\text { Takes into account employees' per- } \\
\text { sonal limitations in organization and } \\
\text { working hours. }\end{array}$ & & $\mathrm{X}$ & $\begin{array}{l}\text { Employees must keep to } \\
\text { their established schedules, } \\
\text { and there is no overtime. }\end{array}$ & & $\mathrm{X}$ & $\begin{array}{l}\text { Working hours are determined in } \\
\text { accordance with the Federal Labor } \\
\text { Law. Flexibility in this area depends } \\
\text { on each enterprise. The permissions } \\
\text { are only given in extreme cases. }\end{array}$ \\
\hline $\begin{array}{l}\text { Provides normal or higher statutory } \\
\text { employment benefits. }\end{array}$ & $\mathrm{X}$ & & $\begin{array}{l}\text { Only those established by } \\
\text { law. }\end{array}$ & $\mathrm{X}$ & & Only those established by law. \\
\hline Employees may join to a union labor. & & $\mathrm{X}$ & & & & $\begin{array}{l}\text { Employees of Hotel Las Palomas and } \\
\text { Hotel Las Palomas Express may join } \\
\text { to a union labor. }\end{array}$ \\
\hline $\begin{array}{l}\text { Employees are trained in health and } \\
\text { safety at work. }\end{array}$ & & $\mathrm{X}$ & & & $\mathrm{X}$ & \\
\hline $\begin{array}{l}\text { Promotes and supports employees for } \\
\text { their training. }\end{array}$ & & $\mathrm{X}$ & & & $\mathrm{X}$ & \\
\hline $\begin{array}{l}\text { Informs employees about the strate- } \\
\text { gic orientation of the enterprise. }\end{array}$ & $\mathrm{X}$ & & $\begin{array}{l}\text { Meetings are held with all } \\
\text { employees. }\end{array}$ & $\mathrm{X}$ & & $\begin{array}{l}\text { Absolutely yes, in fact, it is no longer } \\
\text { marked the pyramid hierarchy as } \\
\text { before. }\end{array}$ \\
\hline $\begin{array}{l}\text { Involves employees in the decision- } \\
\text { making process. }\end{array}$ & & $\mathrm{X}$ & & $\mathrm{X}$ & & $\begin{array}{l}\text { Only employees who work in the } \\
\text { strategic part of the enterprise. }\end{array}$ \\
\hline $\begin{array}{l}\text { Allows employees to participate in } \\
\text { the profits or capital of the enterprise } \\
\text { (e.g. bonds, share purchase, profit } \\
\text { sharing). }\end{array}$ & & $\mathrm{X}$ & & $\mathrm{X}$ & & $\begin{array}{l}\text { All enterprises have profit sharing, in } \\
\text { some others they also give seniority } \\
\text { incentives and incentives to motivate } \\
\text { employees. }\end{array}$ \\
\hline $\begin{array}{l}\text { Consults its stakeholders' group } \\
\text { (employees, suppliers, clients, } \\
\text { creditors, associations, NGOs, etc.) } \\
\text { for their decisions regarding human } \\
\text { resources management. }\end{array}$ & & $\mathrm{X}$ & $\begin{array}{l}\text { For the recruitment of } \\
\text { new staff, a psychometric } \\
\text { and knowledge assessment } \\
\text { is carried out through an } \\
\text { external company. }\end{array}$ & & $\mathrm{X}$ & $\begin{array}{l}\text { When there is a vacancy, all those } \\
\text { who want to compete for it enter, } \\
\text { must have the knowledge required in } \\
\text { the position offered. }\end{array}$ \\
\hline Absenteeism at work is punished. & $\mathrm{X}$ & & According with the law. & $\mathrm{X}$ & & $\begin{array}{l}\text { According with the law: more than } 3 \\
\text { times within } 30 \text { days. }\end{array}$ \\
\hline
\end{tabular}

because they are not taking advantage of the training offered in federal agencies, nor are they taking advantage of moving excess guests to other hotels as a recommendation, neither are they having joint distribution channels that could reduce costs, and this, as the theory points out, may be due to the fact that although the companies are associated for a common purpose there is still rivalry, and that is the main weakness of an inter-business association strategy, because cooperating is giving the best qualities and the other party will also give them, but many companies believe that this puts them at a disadvantage compared to companies in the same sector, therefore, rivalry plays a decisive role, and it is considered that the associations of this research have no gone further for that reason. 
In addition to the above, although it is true that both associations are working well, they have been operating for several years and can be considered successful, so far, they do not generate the measurement indicators: increase in joint sales since they are associated, increase in training, lower turnover. All those indicators that point to an optimal company or association, then they are not generating them for the reason that they are not doing it together, although they directly affect the sector, they let each company make its own decisions.

In this sense, this research is limited, since in the absence of such information a global comparison cannot be made, however, it is believed that both association have served as regards the impact it has the economic development of the locality, because the associations are continuously employing and each time the management positions are being left in charge of people from the same area, they are also receiving sustainability campaigns or some ecological impact, which makes improvements to the community and that, although it is not yet defined in the law as mandatory, they do so in joint improvement, and therefore, they do impact the development of the locality.

With this contrast, there is finally evidence that confirms the theory, that is, the companies that associate are generally micro, small and even medium-sized companies, but that independently they could not advance so fast or they could not achieve their goals quickly, then indeed they have gained strength in the city derived from that cooperation, therefore, the theory is confirmed that business associations allow to activating a sector.

\section{Conclusions}

Among the reasons to support the advancement of MSMEs are considerations related to inter-company association or cooperation, in addition to those related to local business systems, collaboration between them to compete, public-private articulation, knowledge generation by interaction and development of competitive advantages (Silva, 2005).

In the same way, starting from a vision of local intercompany association, it is important to propose the generation of actions that are inclined to improve the performance of both companies and the territory where they are, jointly, through the establishment of bonds of trust, the promotion of business cooperation processes and business sectors with government and private agencies; In addition to promoting the evolutionary processes of specialization and innovation, derived from sharing knowledge and strengthening competitiveness, in order to achieve collective learning (Narváez et al., 2008).

It was thus that in this investigation, when contrasting what was indicated by the theory and what was found in the results, it was concluded that the business associations interviewed have had a positive effect on the economic development of the area, therefore, it is It is important to recommend the establishment of promotion mechanisms and public policies so that more companies decide to work together, and that if they do, they may receive some fiscal stimulus, which encourages and rewards companies that collaborate successfully, and with that, extrapolate it to the rest. of economic sectors. So, it is recommended that existing inter-company associations can associate or link with MSMEs from different sectors, or at least establish strategic alliances with other types of companies, this with the purpose of obtaining greater benefits through productive chains, being more competitive and growing as companies. 


\section{Bibliographic References}

Beltrán, A. (2016). El comercio electrónico en las MIPYMES comerciales de Tepic, Nayarit (Tesis de maestría). Universidad Autónoma de Nayarit, Área de Ciencias Económicas y Administrativas. Tepic, Nayarit, México).

Camacho, L., Morales, R., Flores, G., Aguilar, A., \& Hernández, S. (2013). Gestión del conocimiento para la competitividad de las MiPyME en México. In F. Caballero \& J. Ramírez (Coords.), Gestiones y transferencia del conocimiento en México: casos de estudio (pp. 37-50). México, D.F.: Porrúa.

Castrillo, A. (2019). Asociaciones empresariales en Palencia. Funciones y estilo de gestión (Trabajo de Fin de Grado). Universidad de Valladolid, Facultad de Ciencias del Trabajo. Valladolid, España).

Chang, Y., Chen, M., Lin, Y., \& Gao, Y. (2012). Measuring regional innovation and entrepreneurship capabilities: The case of Taiwan science parks. Journal of the Knowledge Economy, 3(2), 90-108. https://doi. org/10.1007/s13132-011-0081-4

Dini, M. (2010). Competitividad, redes empresariales y desarrollo productivo. Santiago de Chile: Cepal.

Ensari, M., \& Karabay, M. (2014). What helps to make SMEs successful in global markets? Procedia - Social and Behavioral Sciences, (150), 192-201. https://doi. org/10.1016/j.sbspro.2014.09.030

Felzensztein, C., \& Gimmon, E. (2009). Social networks and marketing cooperation in entrepreneurial clusters: An international comparative study. Journal of International Entrepreneurship, 7(4), 281-291. https://doi. org/10.1007/s10843-009-0041-2

Fuentes, N., Osorio, G., \& Mungaray, A. (2016). Capacidades intangibles para la competitividad microempresarial en México. Revista Problemas del Desarrollo, 186(47), 83-106. https://doi.org/10.1016/j.rpd.2016.03.003
Gobierno del Estado de Nayarit. (2012). Plan estatal de desarrollo de Nayarit 2011-2017. Retrieved from https:// www.nayarit.gob.mx/transparenciafiscal/des/3_marco_programatico_presupuestal/Progs_PED.pdf

Gobierno de la República. (2013). Plan nacional de desarrollo 2013-2018. Retrieved from https://www.snieg.mx/ contenidos/espanol/normatividad/MarcoJuridico/ PND_2013-2018.pdf

Gulati, R., Puranam, P., \& Tushman M. (2012). Meta-organization design: Rethinking design in interorganizational and community contexts. Strategic Management Journal, 33(6), 571-586. https://doi. org/10.1002/smj.1975

Instituto Nacional del Emprendedor (INADEM) (2019). Tutoriales del Fondo Nacional Emprendedor 2019. 4. Programas para MIPYMES. Retrieved from https:// tutoriales.inadem.gob. $\mathrm{mx} /$ categoria.php?id=4

Instituto Nacional de Estadística y Geografía (INEGI) (2014). Micro, pequeña, mediana y gran empresa. Estratificación de los establecimientos. Censos Económicos 2014. México, D.F.: Instituto Nacional de Estadística y Geografía. Retrieved from http://internet.contenidos.inegi.org.mx/contenidos/Productos/ prod_serv/contenidos/espanol/bvinegi/productos/ nueva_estruc/702825077952.pdf

Lundrigan, C., Gil, N., \& Puranam, P. (2015). The (under) performance of megaprojects: A metaorganizational perspective. Academy of Management Proceedings, 2015(1), 11299. https://doi.org/10.5465/ ambpp.2015.222

Martínez, M., Aguilera, L., \& Maldonado, G. (2011). Innovación y crecimiento en las MIPYMES del estado de Aguascalientes, 2006-2008. In M. Díaz (Coord.), Desarrollo local sustentable y politicas públicas en Aguascalientes (pp. 124-155). Aguascalientes: Universidad Autónoma de Aguascalientes.

Matinheikkia, J., Pesonen, T., Artto, K., \& Peltokorpi, A. (2017). New value creation in business networks: 
The role of collective action in constructing system-level goal. Industrial Marketing Management, (67), 122-133. https://doi.org/10.1016/j.indmarman.2017.06.011

Narváez, M., Fernández, G., \& Senior, A. (2008). El desarrollo local sobre la base de la asociatividad empresarial: una propuesta estratégica. Opción, 24(57), 74-92.

Plascencia, T., Ramírez, H., \& Pérez, L. (2014). Situación de las micro y pequeñas empresas en Tepic, Nayarit en el ámbito del desarrollo económico local. XIX Congreso Internacional de Contaduría, Administración e Informática. México, D.F.: Universidad Nacional Autónoma de México.

Safón, V. y Castelló-Sirvent, F. (2018). Asociaciones empresariales valencianas: presencia digital e impacto en la sociedad. In A. Cervera y, J. Pastor (Eds.), Valencia y su economia: un modelo sostenible es posible (pp. 123-138). Valencia: Universitat de València.

Secretaría de Economía (4 de setiembre de 2014). Nayarit. Retrieved from http://www.economia.gob.mx/delegaciones-de-la-se/estatales/nayarit\#

Secretaría de Turismo (SECTUR) (2011). ¿Qué es MODERNIZA? Retrieved from http://www.calidad. sectur.gob.mx/moderniza/que-es-moderniza/

Secretaría de Turismo (SECTUR) (2015). Sello de Calidad Punto Limpio. Retrieved from http://www.gob.mx/ sectur/acciones-y-programas/sello-de-calidad-puntolimpio

Secretaría de Turismo (SECTUR) (2016). Programa Mejora tu Hotel. Retrieved from https://www.gob.mx/sectur/ articulos/programa-mejora-tu-hotel-29340
Sistema de Información Empresarial Mexicano (SIEM) (2016). Estadisticas, Municipio, Tipo y Rango de empleados. Retrieved from http://www.siem.gob.mx/siem/ estadisticas/muntamanoPublico.asp?qedo=18\&p=1

Silva, I. (2005). Desarrollo económico local y competitividad territorial en América Latina. Revista de la CEPAL, (85), 81-100. https://doi.org/10.18356/c1a66269-es

Stejskal, J. (2011). Analysis of the applicability of selected methods for industrial clusters identifying. International Journal of Systems Applications, Engineering \& Development, 5(3), 255-262.

Valdés, J., \& Sánchez, G. (2012). Las MIPYMES en el contexto mundial: sus particularidades en México. Iberóforum Revista de Ciencias Sociales de la Universidad Iberoamericana, 7(14), 126-156.

Vélazquez, G. (2007). ¿Las pequeñas y medianas empresas mexicanas requieren aplicar diagnósticos organizacionales? Retrieved from http://www.mundosigloxxi. ciecas.ipn.mx/pdf/v04/13/06.pdf

XL Ayuntamiento de Tepic (2014). Plan municipal de desarrollo de Tepic 2014-2017. Retrieved from http://www. tepic.gob.mx/archivos/PMD2014-2017-Tepic.pdf

Zúñiga, J. (2013). 2013 Reto de las PyMEs en innovación. Retrieved from http://www.pymempresario.com/ destacados/2013-reto-de-las-pymes-en-innovacion/

Fecha de recepción: 18 de octubre de 2019 Fecha de aceptación: 09 de diciembre de 2019 Correspondencia: arianna.beltran.cruz@gmail.com tanaplacu@hotmail.com 